\title{
Monitoring ice break-up on the Mackenzie River using MODIS data
}

\author{
P. Muhammad, C. Duguay, and K.-K. Kang \\ Department of Geography and the Interdisciplinary Centre on Climate Change (IC ${ }^{3}$ ), University of Waterloo, \\ Waterloo, ON, Canada
}

Correspondence to: P. Muhammad (pmuhamma@uwaterloo.ca) and C. Duguay (crduguay@uwaterloo.ca)

Received: 20 March 2015 - Published in The Cryosphere Discuss.: 20 May 2015

Revised: 23 November 2015 - Accepted: 1 December 2015 - Published: 11 March 2016

\begin{abstract}
The aim of this study was to develop an approach for estimating ice break-up dates on the Mackenzie River (MR) using more than a decade of MODIS Level $3500 \mathrm{~m}$ snow products (MOD/MYD10A1), complemented with $250 \mathrm{~m}$ Level 1B radiance products (MOD/MYD02QKM) from the Terra and Aqua satellite platforms.

The analysis showed break-up began on average between days of year (DOYs) 115 and 125 and ended between DOYs 145 and 155 over 13 ice seasons (2001-2013), resulting in an average melt duration of ca. 30-40 days. Thermal processes were more important in driving ice break-up south of the MR confluence with the Liard River, while dynamically driven break-up was more important north of the Liard.

A comparison of the timing of ice disappearance with snow disappearance from surrounding land areas of the MR with MODIS Level 3 snow products showed varying relationships along the river. Ice-off and snow-off timing were in sync north of the MR-Liard River confluence and over sections of the MR before it enters the Mackenzie Delta, but ice disappeared much later than snow on land in regions where thermal ice break-up processes dominated.

MODIS observations revealed that channel morphology is a more important control of ice break-up patterns than previously believed with ice runs on the MR strongly influenced by channel morphology (islands and bars, confluences and channel constriction).

Ice velocity estimates from feature tracking were able to be made in 2008 and 2010 and yielded 3-4-day average ice velocities of 1.21 and $1.84 \mathrm{~m} \mathrm{~s}^{-1}$ respectively, which is in agreement with estimates from previous studies.

These preliminary results confirm the utility of daily MODIS data for monitoring ice break-up processes along the Mackenzie River. The addition of optical and synthetic aperture radar data from recent and upcoming satellite missions
\end{abstract}

(e.g. Sentinel-1/2/3 and RADARSAT Constellation) would improve the monitoring of ice break-up in narrower sections of the MR.

\section{Introduction}

The Mackenzie River basin (MRB) is the largest in Canada and is subject to one of the most important annual hydrologic events. River-ice break-up on the Mackenzie River (MR) is a process by which upstream (lower latitude) ice is pushed downstream while intact ice resists movement downstream (higher latitude) (Beltaos and Prowse, 2009). Ice break-up is defined as a process with specific dates identifying key events in space and time between the onset of melt and the complete disappearance of ice in the river. This is the definition used in previously published literature and will be applied in this paper. Break-up is often associated with flooding in north-flowing systems and is thus an important hydrologic event with many environmental benefits (e.g. geochemical land deposition and lake and groundwater recharge) and detriments (e.g. infrastructure damage and lost economic activity) (Prowse, 2001; Kääb et al., 2013). Investigations of river regimes in high-latitude countries including Canada, the United States, Russia, Sweden and Finland have a long history related to their ice monitoring (Lenormand et al., 2002). This is important as ice freeze-up and break-up records serve as climate proxies responding to changing air temperature patterns (Magnuson et al., 2000). The ice break-up process is nonetheless under-monitored. There is therefore a gap in knowledge when attempting to understand all associated hydrologic parameters due to their highly dynamic nature (Beltaos et al., 2011). 
The shortage of ice observations on the Mackenzie River and other rivers and lakes in Canada is partly the result of budget cuts, which have led to the closing of many operational hydrometric stations (Lenormand et al., 2002). Specifically, ice freeze-up and break-up observations peaked during the 1960-1990s and declined dramatically thereafter following budget cuts from the federal government (Lenormand et al., 2002). In the last decade only, the observational network of discharge and ice measurements on the MRB has declined from 65 to 15 stations. Satellite remote sensing is a viable tool for filling this observational gap. For example, Pavelsky and Smith (2004) were able to monitor ice jam floods and break-up events discontinuously over a 10 -year period (1992-1993, 1995-1998 and 2000-2003) on major highlatitude north-flowing rivers at $500 \mathrm{~m}$ and $1 \mathrm{~km}$ spatial resolutions (the Lena, Ob, Yenisey and Mackenzie rivers) using MODIS and Advanced Very High Resolution Radiometer (AVHRR) imagery. Similarly, Chaouch et al. (2012) showed the potential of MODIS ( 0.25 and $1 \mathrm{~km}$ spatial resolutions) for monitoring ice cover on the Susquehanna River (40$42^{\circ} \mathrm{N}$ ), USA, from 2002 to 2010. Kääb and Prowse (2011) and Kääb et al. (2013) have also shown the effectiveness of remote sensing data acquired at $15,2.5$ and $1 \mathrm{~m}$ spatial resolutions using Advanced Spaceborne Thermal Emission and Reflection Radiometer (ASTER), Panchromatic Remote-sensing Instrument for Stereo Mapping (PRISM) and IKONOS respectively for estimating river-ice velocities. However, these previous studies have been limited to spaceborne stereographic data sets capturing a few ideal (cloudfree) images a year and including revisit times ranging from 2 to 16 days, making detailed temporal studies difficult. Despite these recent advances, studies have yet to be conducted that monitor ice freeze-up and break-up processes by satellite remote sensing over longer periods (i.e. continuously over several years).

The aim of the present study was therefore to develop an approach to estimate key ice break-up dates (or events) on the Mackenzie River over more than a decade using Moderate Resolution Imaging Spectroradiometer (MODIS) data. The paper first provides a description of the procedure developed to monitor ice break-up on the MR. This is followed by a quantification of ice-off dates (spatially and temporally) provided by MODIS data. Next, average ice-off dates are compared for a 13-year period (2001-2013). Lastly, displacement of ice runs calculated with MODIS is used to estimate average ice velocity along sections of the MR.

\subsection{Methodology}

\subsection{Study area}

The geographical area of this study focuses on the Mackenzie River extending from the western end of Great Slave Lake $\left(61.36^{\circ} \mathrm{N}, 118.4^{\circ} \mathrm{W}\right)$ to the Mackenzie Delta $\left(67.62^{\circ} \mathrm{N}\right.$, $134.15^{\circ} \mathrm{W}$ ) (Fig. 1). The study area encompasses the main channel and confluences of the river, including any smaller rivers that feed the Mackenzie. Currently, only four hydrometric stations measure water level and ice on the main channel $(1100 \mathrm{~km}$ long) of the Mackenzie River north of Great Slave Lake. A fifth station located at Fort Providence was shutdown in 2010 (Government of Canada, 2010). The MRB forms the second largest basin in North America, extending beyond the Northwest Territories (NWT) at $1.8 \times 10^{6} \mathrm{~km}^{2}$ (Government of Canada, 2007). Approximately $75 \%$ of the MRB lies in the zones of continuous and discontinuous permafrost with many smaller sub-basins adding to flow at different time periods during the break-up season (Abdul Aziz and Burn, 2006). The MRB experiences monthly climatological (1990-2010) averages of -20 to $-23^{\circ} \mathrm{C}$ air temperature between the months of December and February respectively (Dee et al., 2011). Air temperature increases to an average of $-5^{\circ} \mathrm{C}$ in April with the initiation of ice break-up near $61^{\circ} \mathrm{N}$.

Air temperature plays an important role on the timing of spring freshet (Beltaos and Prowse, 2009; Goulding et al., 2009b; Prowse and Beltaos, 2002) in the MRB. It has therefore been associated with increased flow and the initiation of ice break-up in the basin as a result of snowmelt onset (Abdul Aziz and Burn, 2006). In thermal (over-mature) ice break-up, there is an absence of flow from the drainage basin earlier in the melt season, and the ice remains in place or is entrained in flow until incoming solar radiation disintegrates the river ice increasing water temperatures (Beltaos, 1997). This slow melting process causes a gentle rise in discharge on a hydrograph, with flooding found to be less frequent during that period (Goulding et al., 2009a). In dynamic (premature) ice break-up, the accumulation of snow on the drainage basin is higher and the stream pulse (or spring freshet) from snowmelt is characterized by a high slope on the rising limb of the hydrograph (Goulding et al., 2009b; Woo and Thorne, 2003). In the presence of thick ice downstream, flow can be impeded causing a rise in backwater level and flooding upstream. However, when ice resistance is weak downstream, stress applied on the ice cover can rise with increasing water levels fracturing and dislodging ice from shorelines continuing downstream, eventually disintegrating downstream (Hicks, 2009). This process can continue until certain geometric constraints such as channel bends, narrow sections and islands can stop the ice run causing ice jams (Hicks, 2009). Here, the wide-channel jam is the most common of dynamic events which develops from the flow shear stress and the ice jams' own weight, which is formed by the collapse and shoving of ice floe accumulation and is resisted by the internal strength of the accumulation of ice flows (Beltaos, 2008). As the jam builds with ice rubble, the upstream runoff forces can increase above the downstream resistance, thus releasing the jam and creating a wave downstream that raises water levels and amplifies flow velocities (Beltaos et al., 2012). Observations have shown an initial increase and final decrease in water levels as wave celerity and amplitude attenuates downstream (Beltaos and Carter, 2009). 


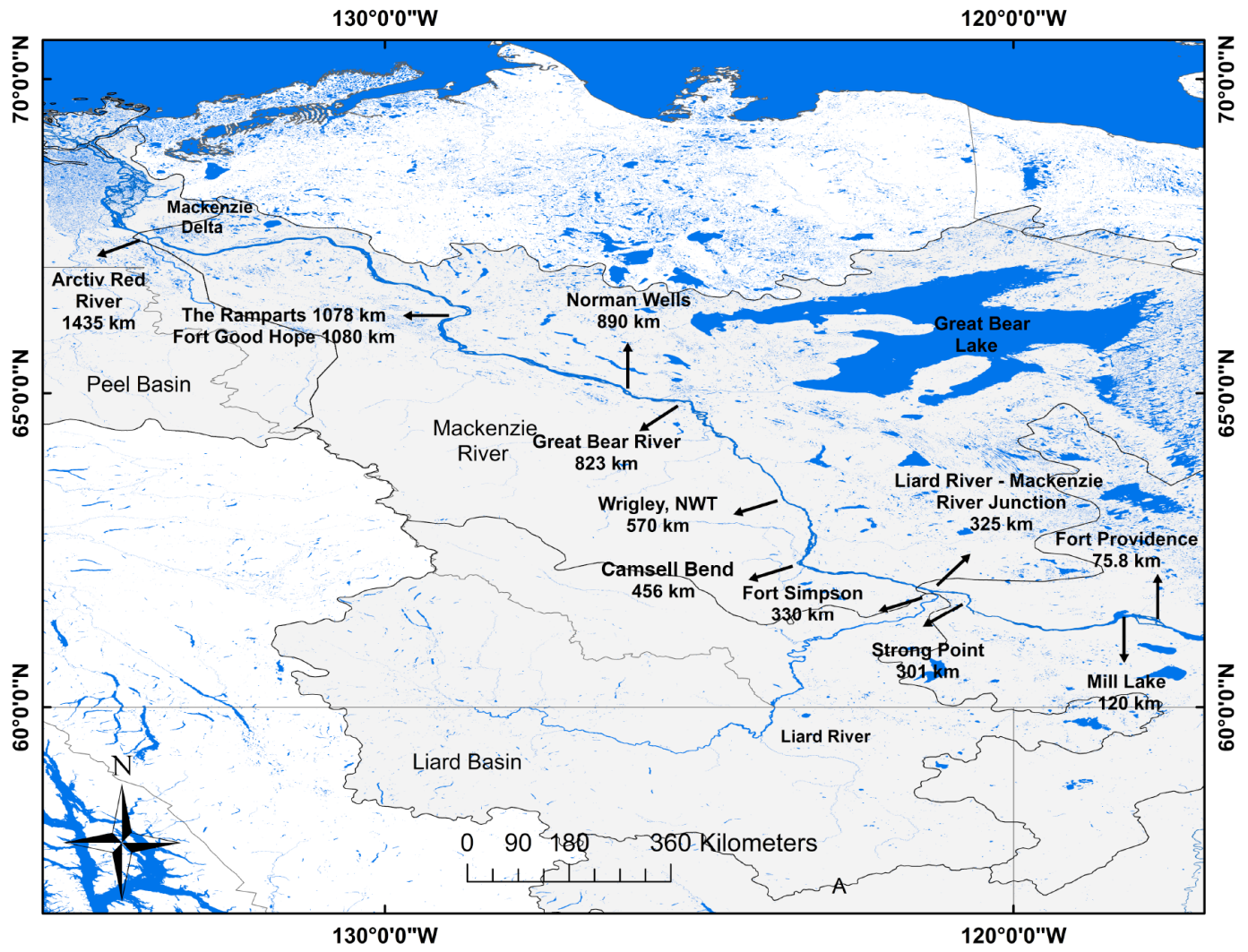

Figure 1. Northern reaches of the Mackenzie River basin (MRB), its sub-basins and major rivers and lakes. The MRB extends from 54 to $68^{\circ} \mathrm{N}$ flowing from the southeast to northwest. The names of sub-basins and tributaries feeding into the Mackenzie River as well as their distances downstream (marked by arrows) from the mouth of the Mackenzie River are also shown.

In general, thermal decay and ice break-up processes continue downstream after the ice jam release (Hicks, 2009). MODIS imagery has also shown the timing of spring flood and location of open-water tributaries to have the most impact on ice break-up processes (Pavelsky and Smith, 2004).

\subsection{MODIS data and processing}

A processing chain was developed in order to determine ice presence or absence (open water) on the Mackenzie River. As seen in Fig. 2, MOD/MYD10A1 Level 3 (primary data set, $500 \mathrm{~m}$ ) was processed in the MODIS Reprojection Toolkit in order to extract specific subsets of scientific data sets (snow, river ice, cloud and open water, as seen in Table 2), perform geographic projections and write output files. Here, the primary data set was resampled using the nearest neighbour method and reprojected to the UTM projection. In the presence of cloud-free images and images where cloud was not covering the MR, open-water observations were recorded on the Mackenzie River. Observations were manually performed along the MR by visual interpretation wherever a cross-section of the river was partially or entirely ice free. When cloud cover was found to be present in the primary data set, which limited ice obser-

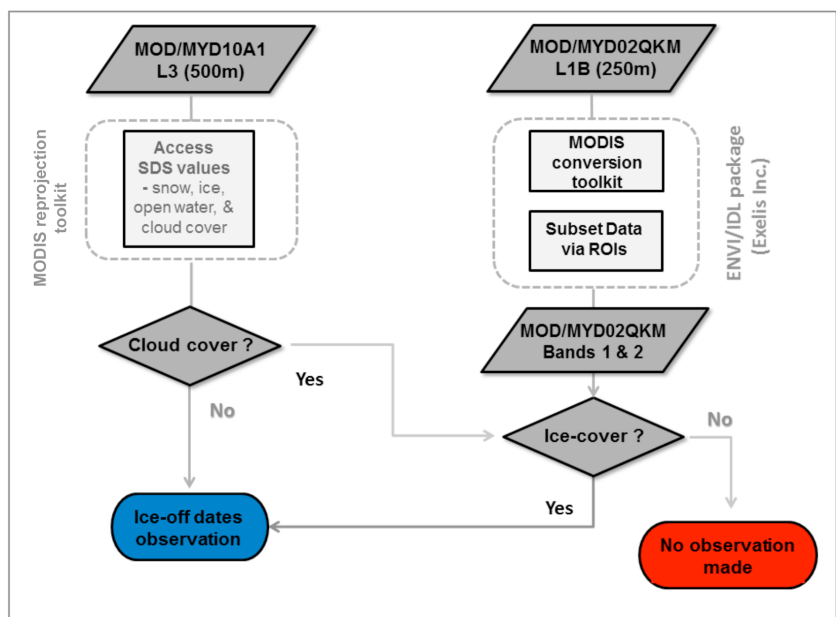

Figure 2. Illustration of the processing steps of ice of observations (manually and by visual interpretation) on the Mackenzie River.

vations, MOD/MYD02QKM Level 1B (secondary data set, consisting of bands 1 and 2 at $250 \mathrm{~m}$ resolution) was used. This MODIS product was processed using the MODIS Conversion Toolkit in the ENVI/IDL package (nearest neighbour 
method/UTM projection). Finally, in the presence of high cloud cover in the secondary data set no observations were recorded.

Through visual interpretation varying land attributes digital number (DN) values (snow, river ice, cloud, open water) in the MOD/MYD02QKM were defined from MOD/MYD10A1 scientific data set (SDS) values of the same land attributes. Observing and comparing the same areas of interest and dates from MOD/MYD10A1 and MOD/MYD02QKM images as seen in Table 2 completed this process. For example, MOD/MYD10A1 images of ice cover at a SDS reading of 100 (river ice) was matched to a $\mathrm{DN}$ value ranging from 40 to 110 from the MOD/MYD02QKM images.

\subsubsection{MODIS data}

MODIS images, for the period from 1 week before to 1 week after the ice break-up period had ended over the MRB from 2001 to 2013, were downloaded from the National Aeronautic and Space Administration's (NASA) Earth observing System Data and Information System (EOSDIS) (http: //reverb.echo.nasa.gov/reverb/) for processing. This study used MODIS data with spatial resolutions of $500 \mathrm{~m}$ (primary data) and $250 \mathrm{~m}$ (secondary data) acquired from both the Aqua and Terra satellite platforms. More specifically, MODIS L1B (MYD02QKM/MOD02QKM) and MODIS Snow Product (L3) (MYD10A1/MOD10A1) data sets were retrieved for analysis. In this paper, the MODIS will generally be referred to as L3 and L1B.

The use of the L3 data product from a single MODIS sensor (Aqua or Terra) limited the potential to obtain frequent ice break-up observations as a result of cloud cover conditions. However, using L3 product from both Aqua and Terra satellites across varying orbital tracks in combination with the L1B product greatly increased the number of observable events during the ice break-up period, up to more than $90 \%$ of available images (Table 3). MODIS acquisitions from both the Aqua and Terra satellites doubled the number of images available during clear-sky conditions. In addition, the availability of MODIS L1B data from Aqua and Terra further increased the number of available images for analysis (i.e. cases where ice could be seen under thin clouds).

\subsubsection{MODIS data processing}

Cloud cover presence was one of the few incidences where image processing was limited. This has also been previously reported (Riggs et al., 2000) where cloud cover in the Arctic limited data acquisition from the study site. This, in combination with coarse-resolution cloud cover masks resulted in 5$10 \%$ of the images being omitted from analysis. Problems in snow detection arise when spectral characteristics important in the use of the normalised difference snow index (NDSI) make it difficult to discriminate between snow and specific cloud types (Hall et al., 2006). NDSI is insensitive to most clouds except when ice-containing clouds are present, exhibiting a similar spectral signature to snow. Hence, some MOD35/MYD35_L2 cloud mask images presented conservative over-masking of snow cover on cloudy and foggy days (Hall et al., 2006).

To improve temporal coverage, ice-off observations were also carried out at varying overpass times (Chaouch et al., 2012) using MODIS L1B radiance products from both Aqua and Terra satellites, which do not include the MOD35/MYD35 cloud mask. During cloud-free conditions, L3 images were used to sample data along sections of the river. Furthermore, to maximise the availability of data collected, MODIS L1B was used when cloud cover was present in L3 swaths. The MODIS snow product at $500 \mathrm{~m}$ spatial resolution presents a cloud mask at $1 \mathrm{~km}$ spatial resolution. Using MODIS L1B enabled a higher availability of recordable pixels at geographic locations, which were cloud covered in the L3 images. It was concluded that more data pixels were available to collect from MODIS L1B when cloud cover was present in L3 images. Image sets of DOYs 100160 were analysed to observe patterns over the entire ice break-up period ranging from 61 to $68^{\circ} \mathrm{N}$. Ice-off observations were recorded at latitudes where ice was present but subsequently absent from images the next Julian day. Northflowing ice could generate multiple ice-on and ice-off dates at the same geographic location. Ice-off and ice-on dates are dynamic ice-run events during the ice break-up period. Multiple ice-off dates observed by satellite imagery were referenced and compared to specific hydrometric stations from the Water Survey of Canada (WSC) along the Mackenzie River (Table 1).

To avoid error in the SDS data collected, mixed pixels over the river consisting of water, ice and land were omitted. Furthermore, in sections of the river where pixel mixing was common as a result of smaller river widths, MODIS L1B was used. MODIS L1B with a spatial resolution of $250 \mathrm{~m}$ enabled to maximise data collection and minimise mixed pixel omission. The use of MODIS reflectance data at the $250 \mathrm{~m}$ spatial resolution (bands 1 and 2) has been compared to highresolution Landsat for ice detection and produced a probability of detection at $91 \%$ (Chaouch et al., 2012). Although it would be useful to compare Landsat high-resolution images to the current MODIS sample of observations, very few Landsat images were available with the targets dates and over the specific region where ice break-up was progressing to produce a comprehensive comparison. The combination of high cloud cover, high revisit cycles and rapid ice break-up processes (ranging from a few hours to a few days) limited the amount usable Landsat images.

\subsection{Ice velocity}

In addition to determining instances of ice break-up events with respect to location and time, this study also explored the 
Table 1. Description of a water survey of Canada hydrometric stations on the Mackenzie River.

\begin{tabular}{lll}
\hline Station name & Coordinates & $\begin{array}{l}\text { Distance downstream from mouth } \\
\text { of Mackenzie River }(\mathrm{km})\end{array}$ \\
\hline Mackenzie River at Fort Providence & $61.27^{\circ} \mathrm{N}, 117.54^{\circ} \mathrm{W}$ & 75.8 \\
Mackenzie River at Strong Point & $61.81^{\circ} \mathrm{N}, 120.79^{\circ} \mathrm{W}$ & 301 \\
Mackenzie River at Fort Simpson & $61.86^{\circ} \mathrm{N}, 121.35^{\circ} \mathrm{W}$ & 330 \\
Mackenzie River at Norman Wells & $65.27^{\circ} \mathrm{N}, 126.84^{\circ} \mathrm{W}$ & 890 \\
Mackenzie River at Arctic Red River & $67.45^{\circ} \mathrm{N}, 133.75^{\circ} \mathrm{W}$ & 1435 \\
\hline
\end{tabular}

Table 2. Scientific data set (SDS) and digital number (DN) values from MODIS L1B and L3 products used for the Mackenzie River.

\begin{tabular}{|c|c|c|c|}
\hline & & $\begin{array}{l}\text { MOD/MYD } \\
\text { L3 (SDS) }\end{array}$ & $\begin{array}{l}\text { MOD/MYD } \\
\text { L1B (DN) }\end{array}$ \\
\hline \multirow{7}{*}{ 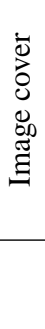 } & Spatial resolution & $(500 \mathrm{~m})$ & $(250 \mathrm{~m})$ \\
\hline & Cloud cover & 50 & $150<$ \\
\hline & Snow & 200 & $111-150$ \\
\hline & Ice (snow covered) & 100 & $40-110$ \\
\hline & Open water & 37 & 30 \\
\hline & Land & 25 & $<28$ \\
\hline & & \multicolumn{2}{|c|}{$\begin{array}{c}\text { Wavelength } \\
\text { (nm) }\end{array}$} \\
\hline \multirow{6}{*}{ 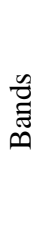 } & 1 & & $620-670$ \\
\hline & 2 & & $841-876$ \\
\hline & 3 & $459-479$ & \\
\hline & 4 & $545-565$ & \\
\hline & 5 & $1230-1250$ & \\
\hline & 7 & $2105-2155$ & \\
\hline
\end{tabular}

use of MODIS as a tool for estimating velocity of ice flows. Ice velocity was observed and recorded on stretches of ice debris $(>15 \mathrm{~km})$ where ice and water demarcation was distinguishable. Stretches of ice were defined by the changes in attributes on the Mackenzie River from open water to ice (37-100) on the leading edge of ice and ice to open water (100-37) on the trailing edge of ice. Velocity was estimated by tracking the displacement of ice over time across multiple MODIS L3 and L1B swaths. Displacement estimates over time were made twice daily from Aqua and Terra satellites image captures. It should be noted that the MODIS images do not show displacement within each image capture; therefore the average velocities represent estimates between images. Average velocities were recorded until ice debris could no longer be distinguished as a result of melt or cloud cover. Ice velocities recorded also represent the lower limit of the ice flows, as the ice may not be moving at all times between image acquisitions. Therefore, the average velocities present time periods when the ice could be at rest and, therefore, the velocity measurements represent underestimation of the actual ice velocities. Ice debris movement was also referenced
Table 3. Time periods of observations and number of MODIS L3 and L1B images analysed during break-up on the Mackenzie River (2001-2013).

\begin{tabular}{|c|c|c|c|c|c|}
\hline \multirow[t]{2}{*}{ Year } & \multirow{2}{*}{$\begin{array}{l}\text { Time period of } \\
\text { observations } \\
\text { (Julian day) }\end{array}$} & \multicolumn{2}{|c|}{$\begin{array}{l}\text { MODIS L3 } \\
\text { images }\end{array}$} & \multicolumn{2}{|c|}{$\begin{array}{l}\text { MODIS L1B } \\
\text { images }\end{array}$} \\
\hline & & Aqua & Terra & Aqua & Terra \\
\hline 2001 & $119-153$ & & 20 & 1 & 1 \\
\hline 2002 & $136-150$ & & 13 & 2 & 1 \\
\hline 2003 & $115-153$ & 16 & 13 & 1 & 1 \\
\hline 2004 & $122-151$ & 9 & 6 & 3 & 2 \\
\hline 2005 & $116-144$ & 14 & 15 & 2 & 2 \\
\hline 2006 & $123-144$ & 12 & 15 & 1 & 1 \\
\hline 2007 & $115-153$ & 23 & 21 & 2 & 4 \\
\hline 2008 & $124-154$ & 18 & 23 & 2 & 4 \\
\hline 2009 & $125-147$ & 15 & 16 & 2 & 1 \\
\hline 2010 & $115-141$ & 17 & 18 & 1 & 1 \\
\hline 2011 & $128-148$ & 16 & 14 & 2 & 2 \\
\hline 2012 & $123-149$ & 20 & 16 & 1 & 2 \\
\hline 2013 & $131-149$ & 14 & 14 & 1 & 1 \\
\hline Total & & 174 & 204 & 21 & 23 \\
\hline
\end{tabular}

to WSC station provided that an operational station was on the route of the ice run.

\subsection{Results}

\subsection{Thermal and dynamic ice break-up}

Over the 13 years of analysis, the ice break-up period ranged from as early as DOY 115 and lasted as late as DOY 155. Most ice break-up over the 13-year period (2001-2013) began between DOYs 115 and 125 and ended between DOYs 145 and 155. River morphology acted as an important spatial control determining the type of ice break-up process and ice run. Ice break-up processes between years showed different overall patterns with respect to location, and thus temporally the beginning, end and duration of ice break-up varied. For example, the initiation of ice break-up in 2002 (Fort Simpson, $330 \mathrm{~km}$ ) began 10 days later than the average date when ice would completely clear the river section. Compared to 2007, the initiation of ice break-up began 13 days 

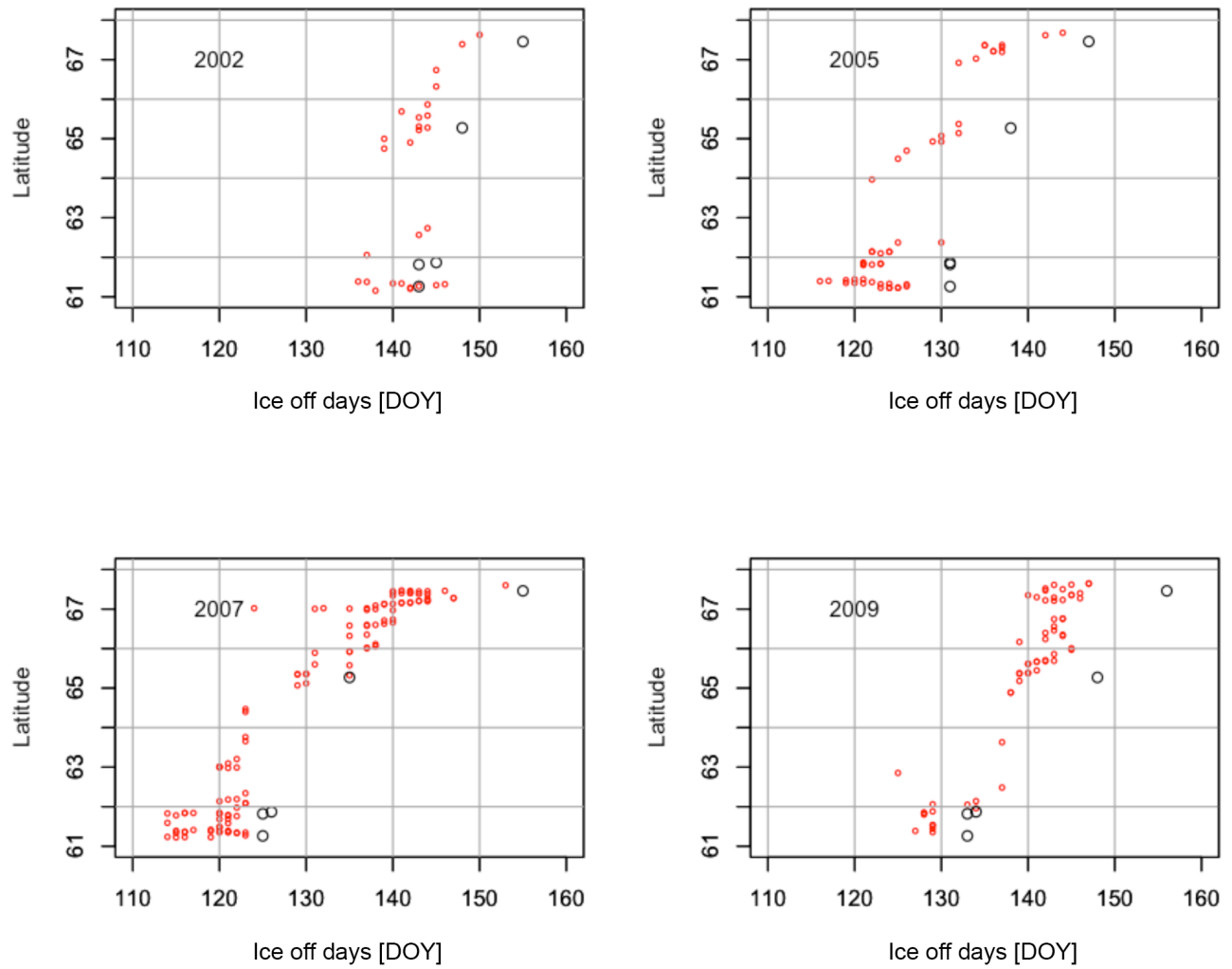

Figure 3. Estimated ice-off dates as illustrated by the red circles for selected years (2002, 2005, 2007 and 2009) on the Mackenzie River. Terra observations were made throughout the study period, while Aqua observations were available 2003-onward. Black circles are indicative of WSC ice observation dates.

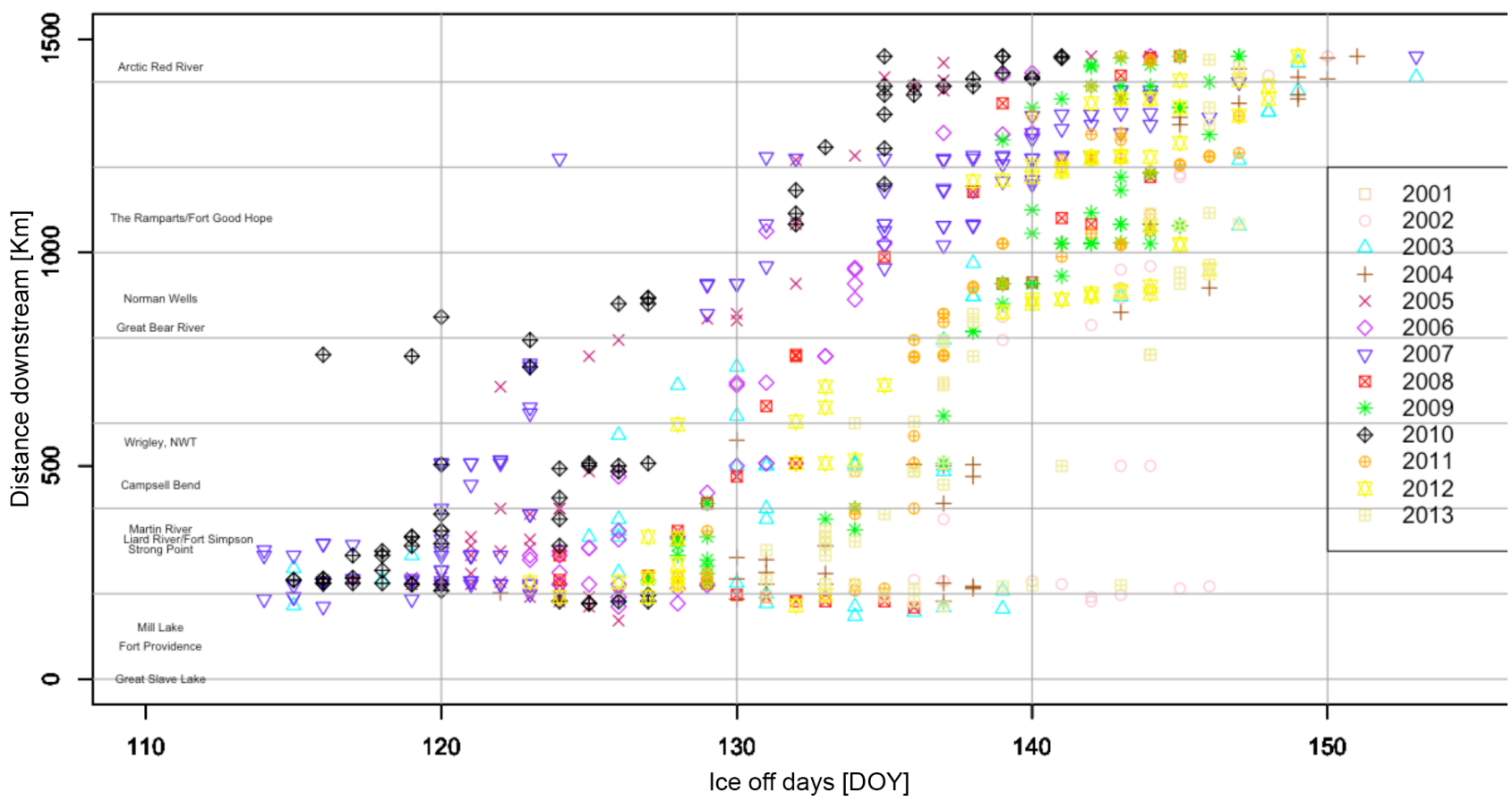

Figure 4. Compilation of all ice-off dates from 2001 to 2013 DOY (day of year) on the Mackenzie River. First ice break-up dates generally began near $325 \mathrm{~km}$. Ice break-up processes are more protracted just south of $325 \mathrm{~km}$ as seen with the higher density of measurements. Near $1078 \mathrm{~km}$, a second channel constriction is present giving rise to two distinct ice-run patterns. 


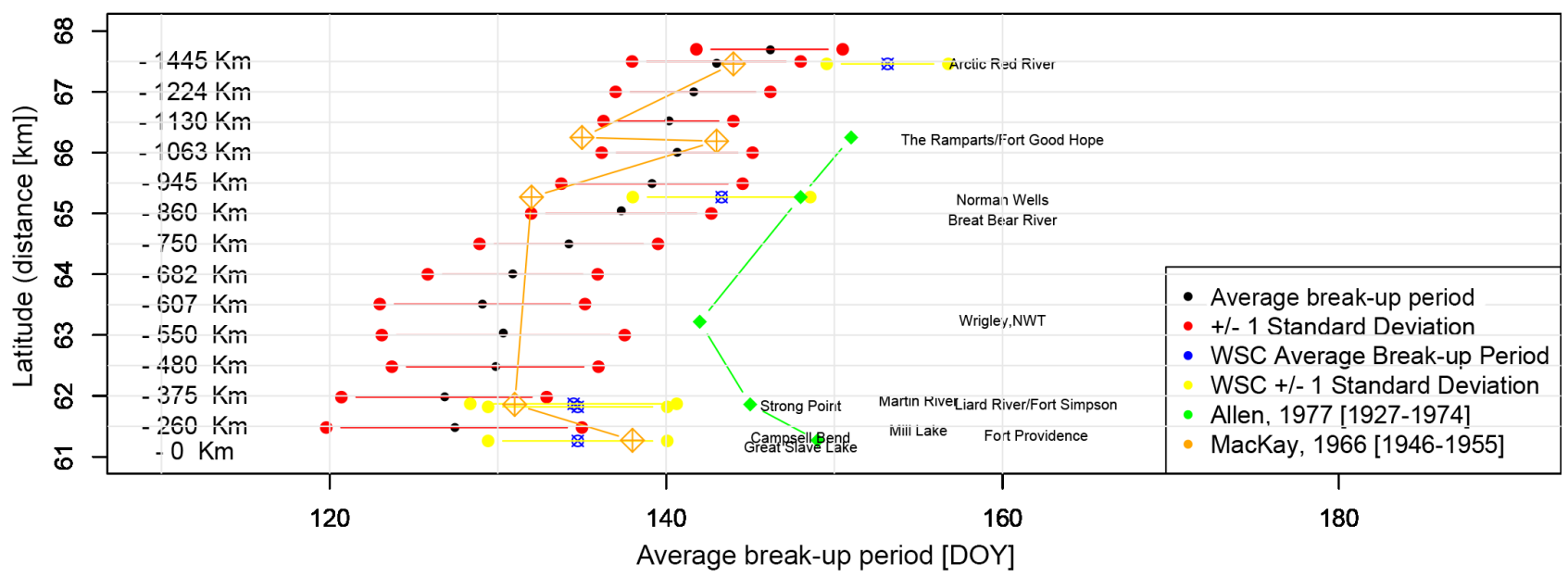

Figure 5. Average ice break-up dates estimated from MODIS (2001-2013) are given by the black dots, with \pm 1 standard deviation indicated by red dots. The blue dots illustrate the WSC average ice break-up dates and the yellow dots \pm 1 standard deviation. The green and orange dots represent average ice break-up dates from Allen (1977) from the time period of 1927-1974 and MacKay (1966) from the time period of 1946-1955 respectively.

earlier than the average ice-off date at $270 \mathrm{~km}\left(61.57^{\circ} \mathrm{N}\right)$. As seen in Fig. 3, ice break-up initiates earliest at the headwaters (headwaters at $120 \mathrm{~km}, 61.43^{\circ} \mathrm{N}$, to $345 \mathrm{~km}, 61.92^{\circ} \mathrm{N}$ ) between Martin River and Mill Lake, and it proceeds northward towards the Mackenzie Delta (see Fig. 4).

The initiation of the ice break-up period on the Mackenzie River was generally observed at the Liard River $(325 \mathrm{~km})$. The beginning and end of ice-off observations were observed to take place sooner near the Liard River than upstream and downstream of this location (Fig. 5). The confluence where the Mackenzie River and Liard River meet $\left(61.82^{\circ} \mathrm{N}\right.$, $325 \mathrm{~km})$ serves as a point where ice break-up proceeds dynamically northbound and thermodynamically southbound. South of $325 \mathrm{~km}$, ice break-up was observed to be driven by a thermodynamic ice break-up regime (Fig. 6). So, ice break-up advanced opposite to the direction of river flow, southbound towards Great Slave Lake. Interestingly, higher frequencies of observations were observed south of $325 \mathrm{~km}$ where thermodynamic ice break-up regime was prevalent. This ice break-up "reverse" to the river flow was observed to continue until it approached Mill Lake, where the ice breakup was simultaneously progressing in the direction of flow. The converging course continued until no ice remained south of Martin River (Fig. 6).

As ice break-up proceeded northbound from the MRLiard confluence, dynamic ice break-up flushed the ice downstream in a shorter period of time than the thermodynamic ice break-up south of the confluence (Figs. 3, 4). Generally, however, distances above $560 \mathrm{~km}\left(63.22^{\circ} \mathrm{N}\right)$ (Wrigley, NWT) on the Mackenzie River experienced later ice breakup dates over the 13 years studied (Fig. 5).

Between 350 and $682 \mathrm{~km}\left(61.96-64^{\circ} \mathrm{N}\right)$ and north of the Mackenzie River and Liard River confluence, the average ice-off date for the study period was observed at DOY 130 . The river width between 350 and $682 \mathrm{~km}$ was found to be smaller than reaches upstream (feeding ice into the main river channel) and downstream (letting ice exit the channel) as seen in Fig. 7. Consequently, the movement of ice into this river reach was limited, causing ice entering the channel to jam while ice exiting the channel present from the winter period cleared sooner. There is also the possibility that the release of ice javes (river waves generated from ice jam) at the entrance of the channel could give rise to the rapid clearance of downstream ice over a 1-2-day period over this $230 \mathrm{~km}$ stretch of the Mackenzie River (Beltaos et al., 2011).

Downstream of $682 \mathrm{~km}\left(64^{\circ} \mathrm{N}\right)$, river sections showed diagonal ice-off observations as seen in Figs. 3 and 4. These patterns are most visible in 2001, 2007-2009 and 2011-2012 observed between 860 and $1460 \mathrm{~km}\left(65-67.62^{\circ} \mathrm{N}\right)$. Observations of these diagonal events were the result of a second channel constriction at the Ramparts $\left(1078 \mathrm{~km}, 66.19^{\circ} \mathrm{N}\right)$ as seen in Fig. 7, preventing northerly ice run. Here, the river channel decreased from $4 \mathrm{~km}$ to less than $0.5 \mathrm{~km}$ in width. It is hypothesised that ice runs downstream of the Ramparts (as a result of an ice jam) gave rise to similar ice-off dates (estimated at the southern ice/water boundaries of these flows) to ice runs towards the Ramparts. It is estimated that ice jams due to sudden decreases in river width as seen in 2001, 2007-2009 and 2011-2012 gave rise to earlier ice-off dates for river sections north of the jam, resulting in impeded ice run which would normally maintain ice-on condition. This phenomenon resulted in a sequence of ice-off observations that occur simultaneously at two different latitudes, north and south of the ice jam. This further outlines the important morphological controls on the Mackenzie River over ice runs. 


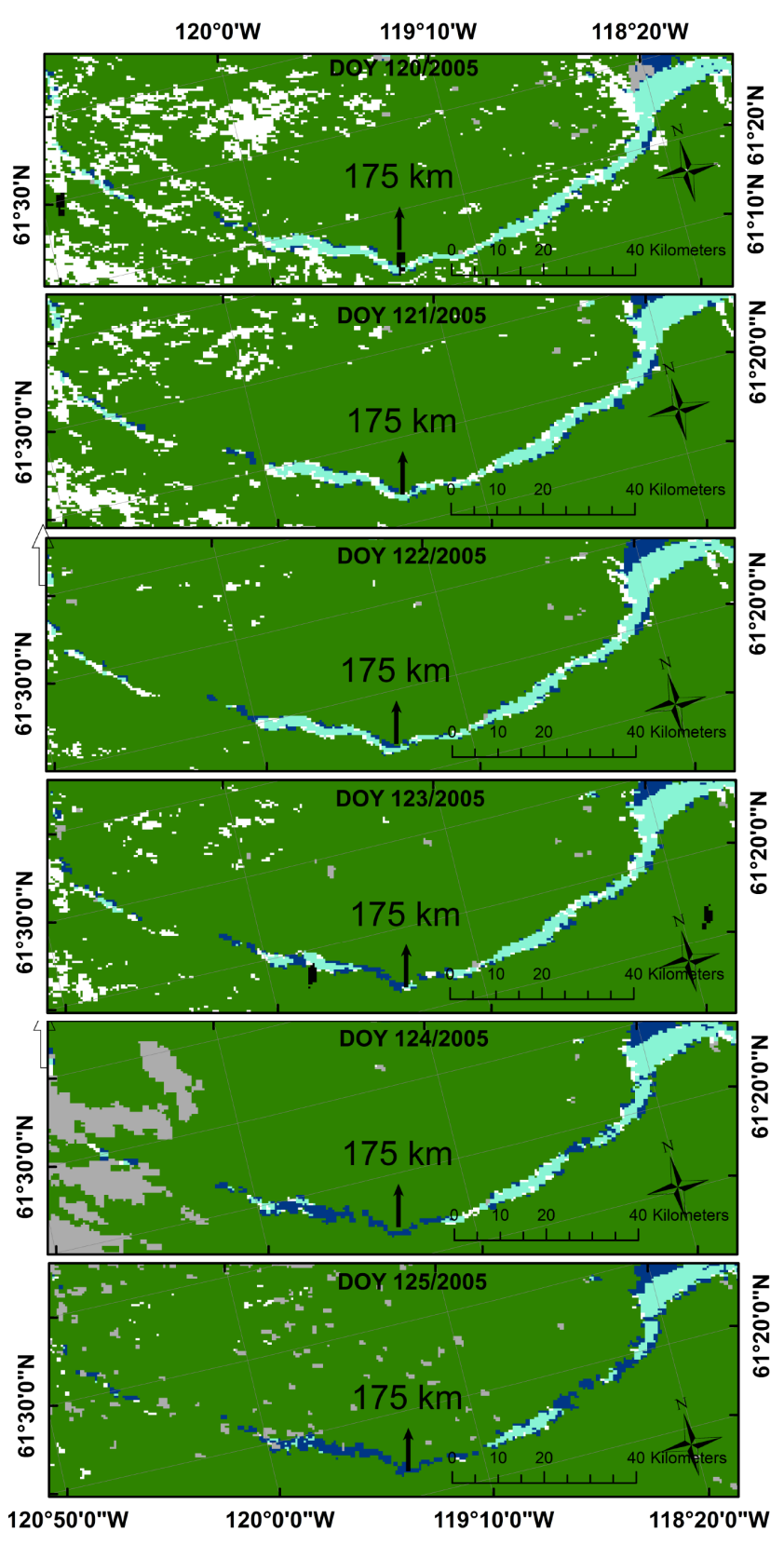

\section{Legend}

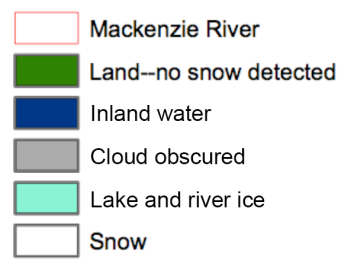

Figure 6. This example illustrates ice break-up at the headwaters of the Mackenzie River system in 2005 from DOYs 120 to 125.
Based on MODIS imagery, ice break-up began on average between DOYs 115 and 125 and ended between DOYs 145 and 155 (Fig. 5). The standard deviation of estimated iceoff dates decreased with increasing latitude. MODIS-derived dates showed highest deviations across river sections where thermodynamic ice break-up was prevalent. These patterns are similar to those seen from average break-up and standard deviations observed from the WSC. The 13-year average reveals similar ice conditions in the low, mid- and high latitudes of the Mackenzie River from MODIS and WSC data. There was an observed difference of 5 days between ice break-up observed from MODIS imagery and WSC. Also, the respective standard deviations overlap across the similar periods. Ice break-up in general continued in a north to south direction over the ice break-up periods. Near Forth Simpson $\left(330 \mathrm{~km}, 61.85^{\circ} \mathrm{N}\right)$, it is worth mentioning that ice break-up was observed earlier than at more southern latitudes as illustrated by MODIS observations. This pattern is likewise visible from the WSC data.

\subsection{Ice break-up and snowmelt}

In order to assess the relative timing of ice disappearance in relation to its surrounding sub-basin, the timing of riverice disappearance was qualitatively compared to the timing of near complete snow disappearance from the surrounding area. MODIS L3 imagery of different years was selected which clearly revealed ice-snow relation with respect to location, where cloud cover was a minimal issue.

Locations where thermodynamic ice disappearance was hypothesised (south of $61.8^{\circ} \mathrm{N}, 325 \mathrm{~km}$ ) corresponded with patterns where ice disappeared much later than snow on land (Fig. 6). For example, DOY 121/2006 (Fig. 8) was observed to be the beginning of the snowmelt period at 290 $487 \mathrm{~km}\left(61.75-62.5^{\circ} \mathrm{N}\right)$ and this process ended when the snow had almost completely disappeared by DOY 125 . However, DOY 125 corresponded to the initiation of ice break-up. This was not limited to 2006 so that snow generally disappeared sooner from surrounding sub-basins, followed by the initiation of ice break-up.

At reaches north of the MR-Liard River confluence, ice break-up and snowmelt were observed to initiate in sync with one another. As seen in Fig. 9, on DOYs 136-137/2011, ice disappearance on the southern cross-section of the figure is marked by the near simultaneous disappearance of snow. In fact by DOY 140/2011 both ice and snow had completely disappeared analogous to each other. On sections of the Mackenzie River before it enters the Mackenzie Delta, estimated ice break-up and snow disappearance was again observed to occur almost simultaneously (Fig. 12). Over a 6-day period (DOYs 137-142/2007) the ice breakup process continued until ice completely disappeared from the channel (MR). This process ensued sooner relative to complete snowmelt over the surrounding sub-basins. By DOY 142/2007 nearly one-third of the river was completely 

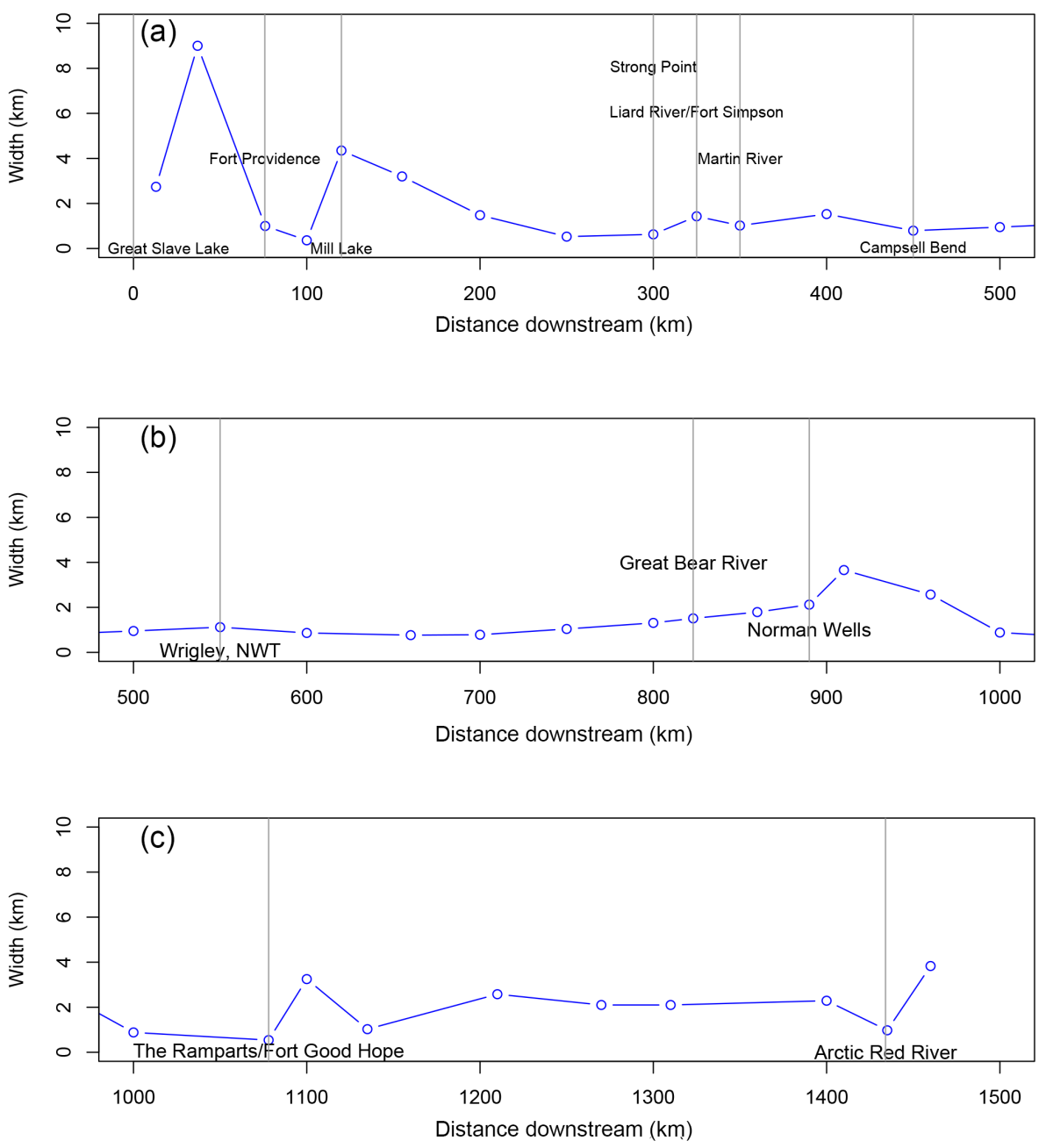

Figure 7. Change in channel width along the Mackenzie River as observed in (a) (ca. 0-500 km), (b) (ca. 500-1000 km) and (c) (ca. 1000$1500 \mathrm{~km})$.

cleared of ice while most of the snow was still present over the MRB.

Principally, it was concluded that on the upper Mackenzie Basin snow cleared sooner than the initiation of ice break-up. In the mid-Mackenzie Basin $\left(375-860 \mathrm{~km}, 62-65^{\circ} \mathrm{N}\right)$, river ice cleared in situ to snow clearance from the surrounding basin. In fact, ice cleared sooner in the mid-basin than the upper Mackenzie Basin. Finally, in the lower Mackenzie Basin, river ice cleared sooner than the snow from the surrounding basin. This could be telling of a river continuum of the buildup of mechanical strength used to clear river ice within the Mackenzie River towards higher latitudes. The Liard River tributary accounts for one-third of the total Mackenzie discharge (Woo and Thorne, 2003), and so a rise in discharge in May initiates earlier ice break-up downstream as a result of increased stress induced on ice by a rise in river stage. Mechanical stress used to shove ice is continually magnified by the addition of small and large tributaries downstream of the Mackenzie River (Great Slave River, Arctic Red River).

\subsection{River-ice velocity}

Figures 10 and 11 illustrate ice movement from which ice velocities could be estimated over periods of 3-4 days following secondary channel constriction at $66^{\circ} \mathrm{N}$. Here, ice runs that contained over $15 \mathrm{~km}$ of entrained ice were chosen to estimate average ice velocities. Only periods with at least three images with partial or no cloud cover were selected for velocity estimates.

In 2008, the open-water/ice boundary (leading edge) was recorded beginning on DOY 143 (Fig. 10). The openwater/ice (northern edge of ice) and ice/open-water (following edge) boundaries were both visible from DOY 144 . Finally, the ice/open-water boundary was last observed on DOY 145. The average ice-run velocity between 1063 and $1210 \mathrm{~km}\left(66-66.95^{\circ} \mathrm{N}\right)$ over the 3 days was estimated to be at least $1.21 \mathrm{~m} \mathrm{~s}^{-1}$. Likewise, in 2010 (Fig. 11), openwater/ice (leading end) and ice/open-water (following end) was observed between DOYs 138 and 141. The leading edge 

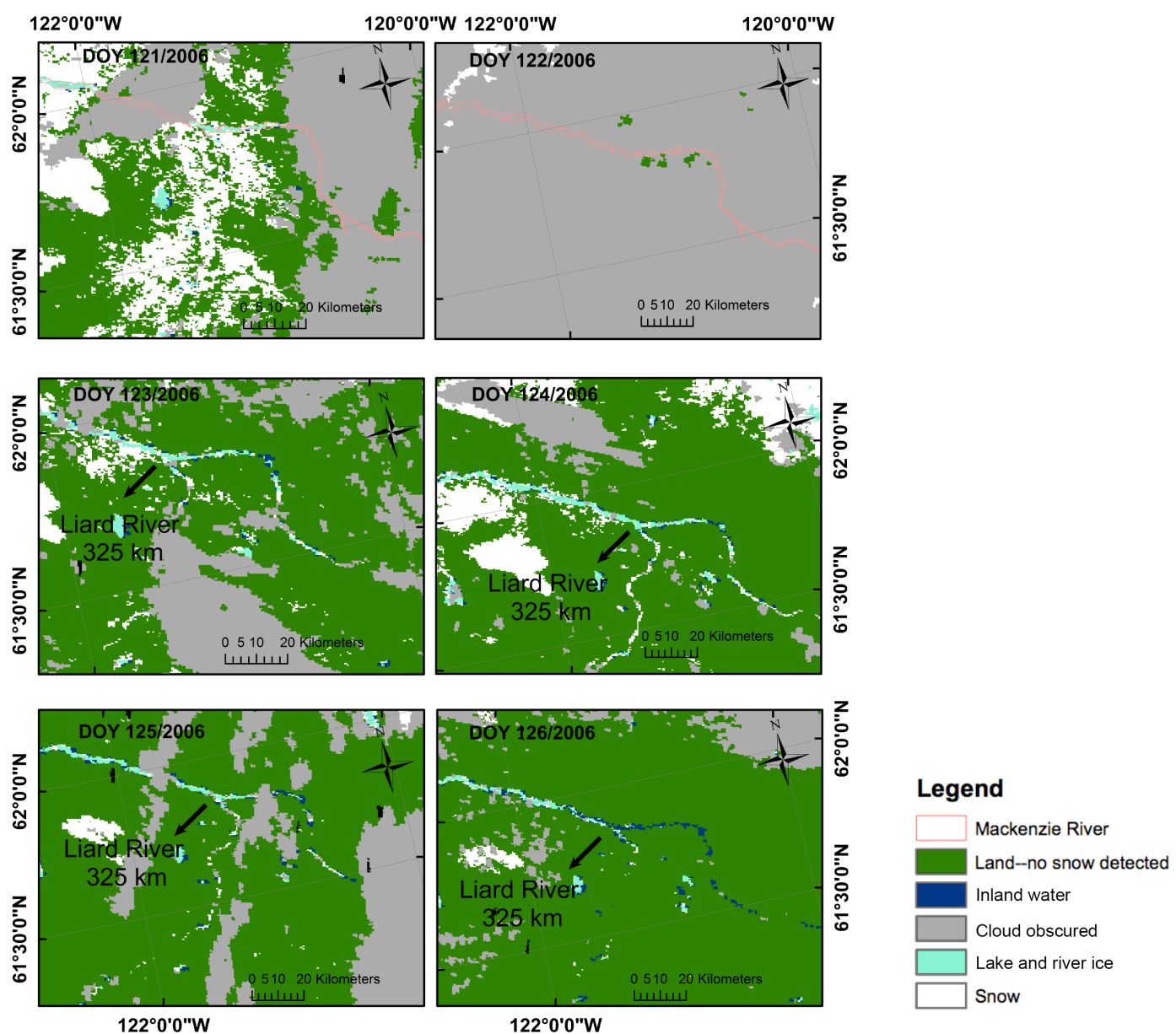

Figure 8. Example of thermodynamic break-up, where ice within the river requires an extra 2-3 days to be cleared after snow has melted over the immediate drainage basin. This process was observed in 2006 between DOYs 121 and 126.

of the ice was first observed on DOY 138 and on DOY 139 when both the leading and following edges are visible. Finally, by DOY 141 the ice run has exited into the Mackenzie Delta. Across the 4-day period average ice-run velocity was estimated to be at least $1.84 \mathrm{~m} \mathrm{~s}^{-1}$.

\section{Discussion}

\subsection{Spatial and temporal ice break-up patterns}

Over the 13-year period, the average estimated ice break-up dates were found to range from DOYs 115 to 155 between distances 60 and $1460 \mathrm{~km}$. These estimates from MODIS are in agreement with break-up dates reported by the WSC ground-based network. Previous studies on the MR, between the late 1930s to 2002, have found the initiation of ice breakup to range from DOYs 123 to 140 between 0 and $1217 \mathrm{~km}$ (de Rham et al., 2008a). Furthermore, it was reported by de Rham (2008b) that the duration of average ice break-up ranged from 8 to 10 days over the entire basin. With respect to the findings reported in Fig. 5, the observed ice break-up patterns agree, such that the average observed break-up dates over the 13-year period ranged from DOY $128 \pm 8$ days at $61.5^{\circ} \mathrm{N}(260 \mathrm{~km})$ to $145 \pm 4$ days at $68^{\circ} \mathrm{N}(1460 \mathrm{~km})$. Others have reported, using MODIS and AVHRR imagery acquired between 1992 and 2002, that ice break-up ranged from DOYs 120 to 155 (Pavelsky and Smith, 2004). The earliest reports of mean ice break-up dates ranged from 15 May (DOY 135) to 25 May (145) (1946-1955 averages), from Fort Providence to Arctic Red River respectively (MacKay, 1966). Furthermore, others have reported a range of ice break-up dates from 22May (DOY 142) to 31 May (DOY 151) (1927-1974, Fig. 3) from Fort Providence to Fort Good Hope, NWT, respectively (Allen, 1977). A summary of the approaches and results reported in these previous investigations as well as those from this study are compared in Table 4.

In the headwaters of the Mackenzie River, ice break-up initiates the earliest between Mill Lake $\left(120 \mathrm{~km}, 61.43^{\circ} \mathrm{N}\right)$ and Martin River $\left(345 \mathrm{~km}, 61.92^{\circ} \mathrm{N}\right)$. As seen in Figs. 35 , ice break-up between 120 and $300 \mathrm{~km}$ initiated earlier 

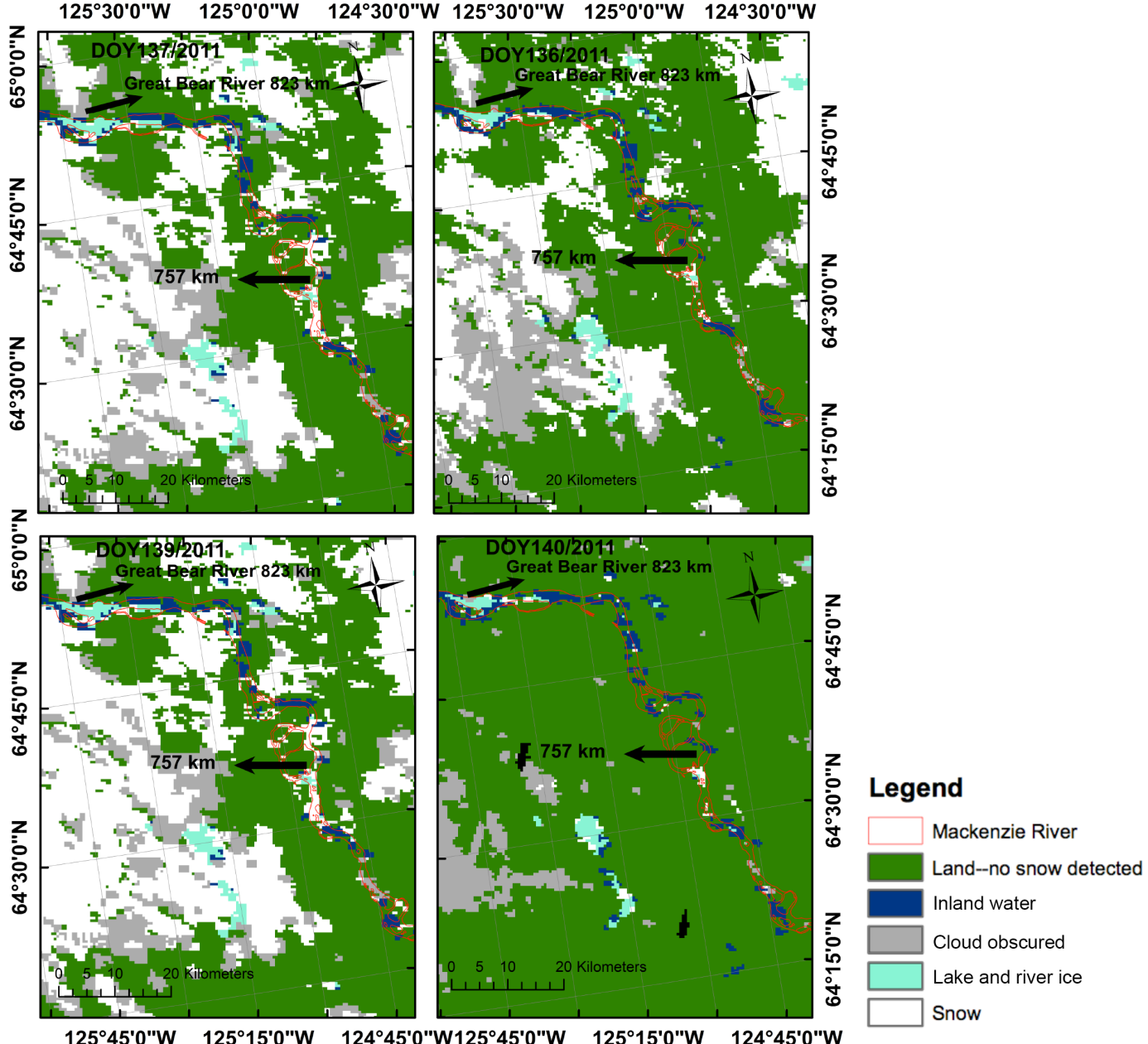

Figure 9. Snowmelt and ice run over the Mackenzie River basin in 2011 between the DOYs 137 and 140. There is a 2-day lag between the complete clearance of snow on land and the clearance of ice on the Mackenzie River.

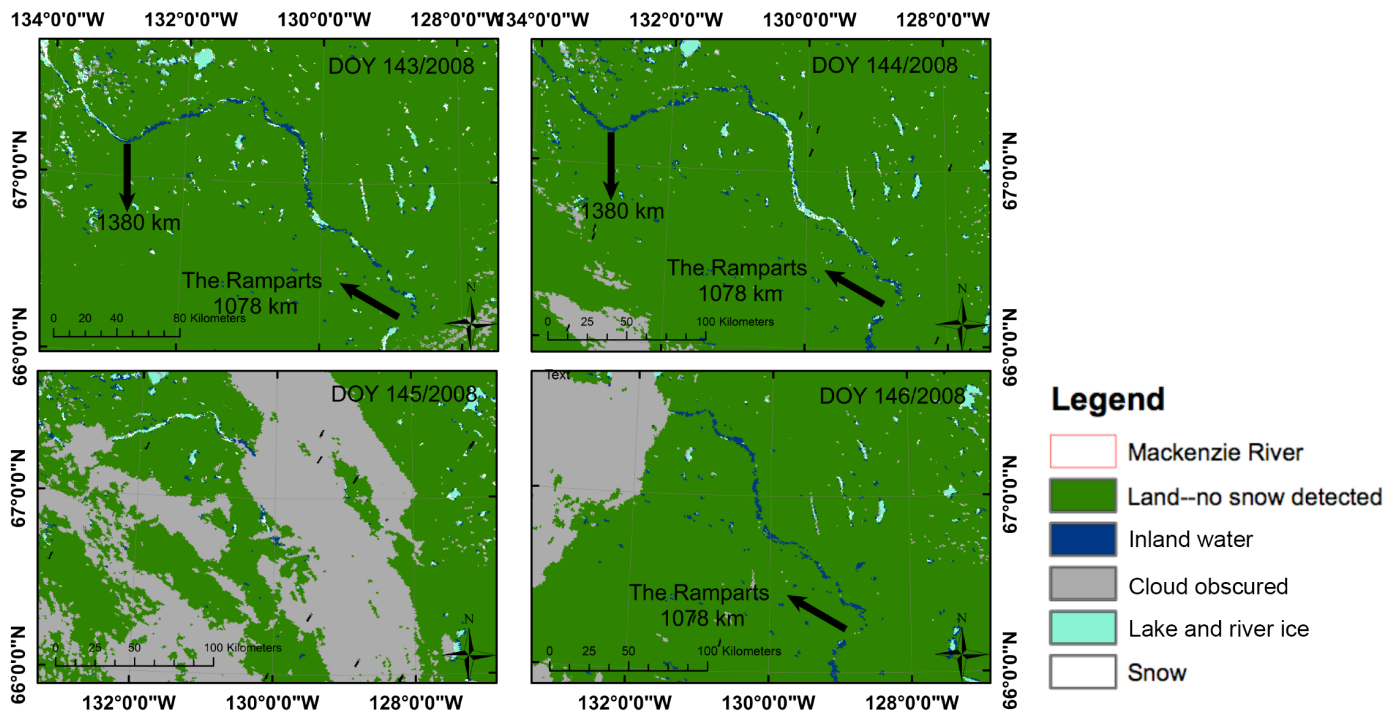

Figure 10. Ice flushing event recorded in 2008 between DOYs 143 and 146. 

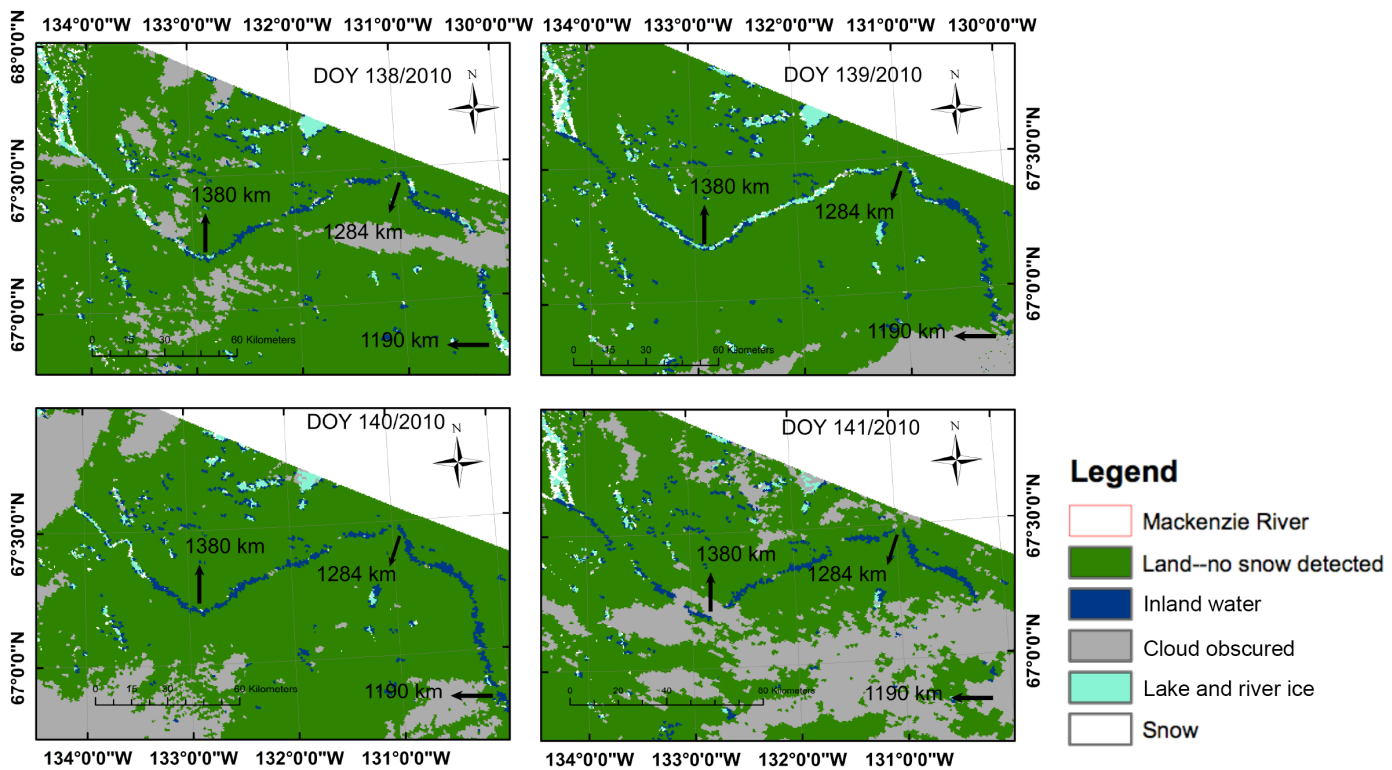

Figure 11. Ice flushing event recorded in 2010 between DOYs 138 and 141. Here, on DOY 141, the ice movement is last recorded after exiting into the Mackenzie Delta.
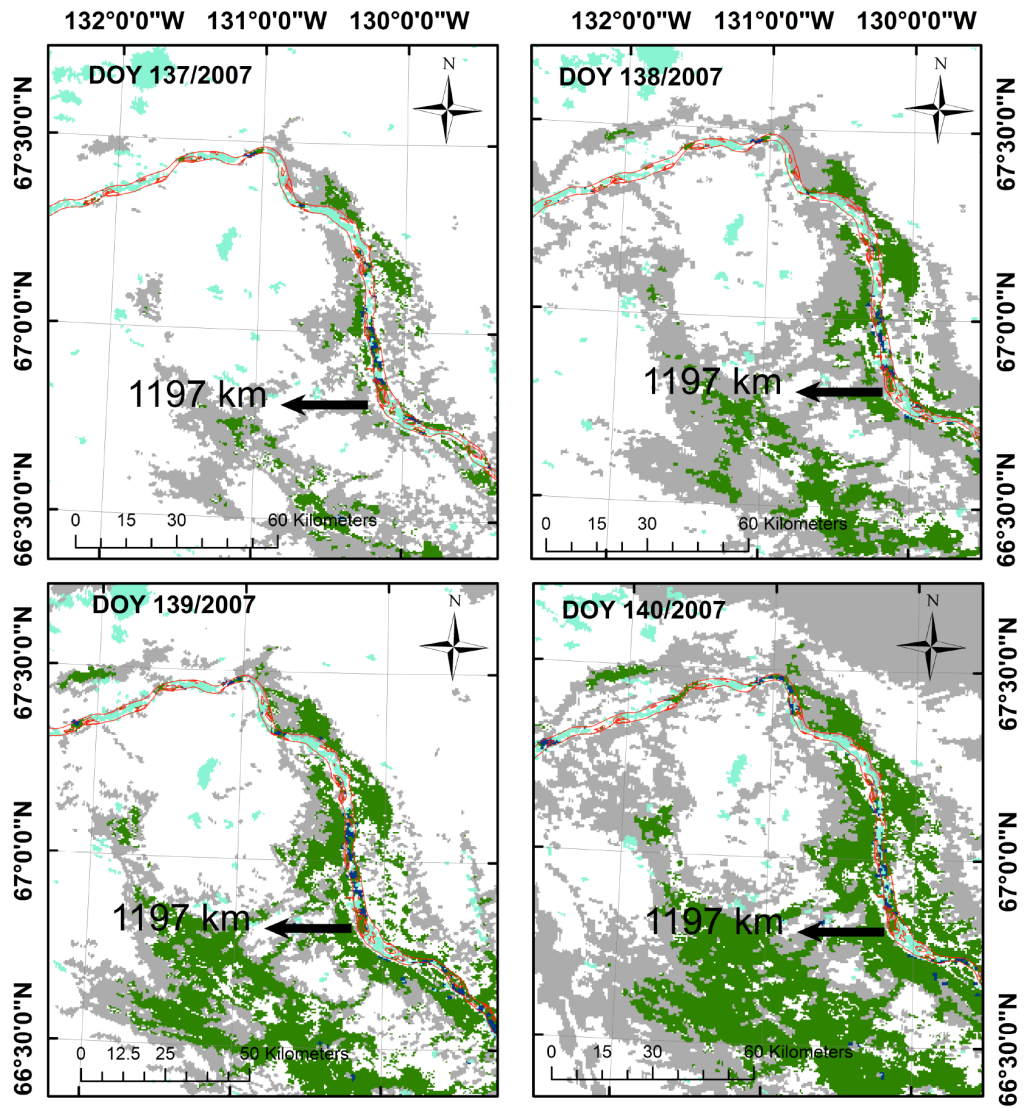

\section{Legend}

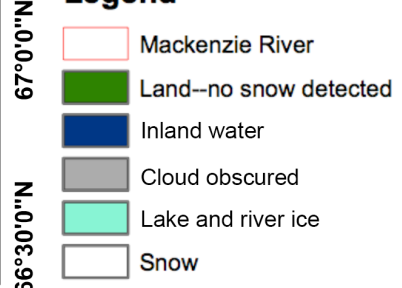

Figure 12. Observation of dynamic break-up over a section of the Mackenzie River basin, showing concurrent ice break-up and snowmelt over 6 days. This was observed in 2007 between DOYs 137 and 142. 
Table 4. Summary of results from previous investigations and this study showing the beginning and end of the ice break-up period with respect to location and range and duration of period. Also shown are the sources of data used, years covered for analyses and corresponding references.

\begin{tabular}{|c|c|c|c|c|c|c|c|}
\hline & & \multirow[b]{2}{*}{$\begin{array}{l}\text { Distances } \\
(\mathrm{km})\end{array}$} & \multirow[b]{2}{*}{ This study } & \multicolumn{4}{|c|}{$\begin{array}{l}\text { Beginning and end of ice break-up dates relative to distance on } \\
\text { the Mackenzie River as reported by previous investigations (Julian days) }\end{array}$} \\
\hline & & & & & & & \\
\hline \multirow{6}{*}{ 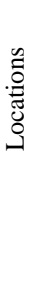 } & Great Slave Lake & 0 & & & Beginning at 120 & & \\
\hline & Fort Providence & 75.8 & Beginning at $128 \pm 8$ days & Beginning at 123 & & Beginning at 135 & Beginning at 142 \\
\hline & Camsell Bend & 456 & & & & & \\
\hline & Fort Good Hope & 1080 & & End at 140 & & & End at 151 \\
\hline & Arctic Red River & 1437 & & & & End at 145 & \\
\hline & Mackenzie River End & 1460 & End at $145 \pm 4$ days & & End at 155 & & \\
\hline \multicolumn{2}{|c|}{ Range of break-up dates } & & $\begin{array}{l}\text { Beginning at } \pm 8 \\
\text { End at } \pm 4 \text { days }\end{array}$ & $8-10$ days & N/A & N/A & N/A \\
\hline \multicolumn{2}{|c|}{ Data source } & & MODIS & $\begin{array}{l}\text { WSC Hydrometric } \\
\text { stations }\end{array}$ & MODIS/AVHRR & Ice Surveys & $\begin{array}{l}\text { WSC Hydrometric } \\
\text { Stations }\end{array}$ \\
\hline \multicolumn{2}{|c|}{ Years covered } & & 2001-2013 & 1930s-2002 & 1992-2002 & 1946-1955 & 1927-1974 \\
\hline \multicolumn{2}{|c|}{ Reference } & & & de Rham ( 2008b) & $\begin{array}{l}\text { Pavelsky and } \\
\text { Smith (2004) }\end{array}$ & MacKay (1966) & Allen (1977) \\
\hline
\end{tabular}

as compared to other sites on the Mackenzie River, but ice cleared later than other for other river sections downstream. Here ice in the channel remains stagnant for extended periods of time as ice usually freezes to bed and is most susceptible to thermodynamic melt (MacKay and Mackay, 1973).

Furthermore, at the Liard River confluence $(325 \mathrm{~km}$, $61.84^{\circ} \mathrm{N}$ ) it was found that the seasonal initiation of ice break-up began and cleared earliest at this central location where the Liard River converges into the MR. Others (Pavelsky and Smith, 2004) have noted that at the MRLiard River confluence flooding is common between years, especially near channel junction. Ice break-up at the Liard River confluence occurs rapidly, as the flow contribution is of greater magnitude than the Mackenzie River (MacKay and Mackay, 1973). This causes a lifting of the river stage, exerting pressure on the ice cover and resulting in ice jam downstream most often attributed to the presence of channel bending (Camsell Bend, $456 \mathrm{~km}$ ) and channel constriction. Similar processes have also been reported for the Susquehanna River, USA, where an observed increase in discharge downstream fosters earlier ice break-up while sections of the upper river remain ice covered (Chaouch et al., 2012). The severity of ice break-up stage is therefore largely controlled by upstream discharge (Goulding et al., 2009b). Pavelsky and Smith (2004) also observed irregularities in ice break-up timing between years, particularly at $325 \mathrm{~km}$ (MR-Liard confluence) on the MR. Here, ice break-up began earlier at distances north of $325 \mathrm{~km}\left(61.8^{\circ} \mathrm{N}\right)$ than river sections south. Postponed ice break-up in the upper Mackenzie can result from the lack of discharge required to initiate ice break-up and so the ice is thermodynamically disintegrated.
Channel morphology is, therefore, a more important control on ice break-up patterns than previously believed. Both Pavelsky and Smith (2004) and de Rham et al. (2008a) alluded to the fact that channel morphology may exert influences on the patterns of ice break-up. De Munck et al. (2011), through the use of geospatial modelling on the Chaudière River identified that channel islands, confluences and channel sinuosity predisposed the Chaudière River to ice jamming events. In this study, it is determined that channel constriction at $350-682 \mathrm{~km}\left(61.96-64^{\circ} \mathrm{N}\right)$ and $1078 \mathrm{~km}$ (the Ramparts) is responsible for the delay of ice break-up timings upstream while promoting earlier ice break-up downstream. Upstream of the Liard River junction, river flow is stable. However, excessive discharge supplied by the Liard River causes earlier ice break-up and ice jamming downstream when the channel constricts between 350 and $682 \mathrm{~km}$ (MacKay and Mackay, 1973). Furthermore, excess supply of ice cover from the Great Bear River $(821 \mathrm{~km})$ into the Mackenzie River causes the development of ice jamming at the Ramparts when the channel width decreases from over $3.5 \mathrm{~km}$ to less than $0.6 \mathrm{~km}$ (as seen in Fig. 7) (MacKay and Mackay, 1973).

Ice jamming from channel width decreases gave rise to similar sequences of ice-off observations, which occurred in tandem at two different latitudes, north and south of the ice jam (as seen at the Ramparts). Ice jams are therefore favourable where morphological features impede downstream ice passage (Beltaos, 1997). These ice jams are caused by channel constriction resulting from mid-channel islands and narrow reaches (Terroux et al., 1981). Channel braiding, constriction and changes in slope have also been reported to be important factors influencing ice break-up 
and flow regimes (de Rham et al., 2008a). In the context of our study, it was found that channel constrictions and bends represented locations where ice runs were impeded. Hicks (2009) also reported that running ice may be stalled when geometric constraints such as tight bends, narrow sections and islands are present in rivers. In fact, it has been shown that ice debris flow drop to a velocity of 0 in the presence of flow depths near channels islands and bars (Kääb et al., 2013). Lastly, Kääb and Prowse (2011), using ALOS PRISM stereo imagery on the Mackenzie River determined that ice velocities decrease to 0 in the presence of bars.

The estimated ice-run events illustrated in Figs. 7 and 10 may have been caused by ice jam releases (javes) initiated at the Ramparts $\left(1078 \mathrm{~km}, 66.19^{\circ} \mathrm{N}\right)$. Such processes may also be the reason why ice was estimated to be cleared at higher latitudes before the end of the snowmelt period. Accumulated stress with the rise of water levels behind the jam can result in sufficient kinetic energy to clear river ice downstream before the complete snowmelt overlying the surrounding subbasins.

\subsection{Ice velocities}

Ice-run velocities are believed to be the highest where the ice is minimally effected by channel morphology, unconnected from incoming tributaries, and channel splitting which causes the formation of islands (Kääb et al., 2013). Amongst the variety of ice runs observed over 13 years, ice velocities could be quantified in 2008 and 2010. Over 3-4-day periods, average ice velocities were estimated to be $1.21 \mathrm{~m} \mathrm{~s}^{-1}$ (2008) and $1.84 \mathrm{~m} \mathrm{~s}^{-1}$ (2010). More importantly, it is believed that the evolution of such velocities is the product of javes. Our measurements of ice-run velocity in 2008 coincidently synchronise with other independent satellite- and ground-based ice measurements. Extensive measurements of ice runs in 2008 around MR-Arctic Red River junction are believed to be generated by waves released from released ice jams (Beltaos, 2013). This aligns with ice jams which may form at the Ramparts $(1078 \mathrm{~km}$, $66.19^{\circ} \mathrm{N}$ ) as a result of channel constriction. The evolution of ice runs north of the Ramparts (flowing past the Arctic Red River) observed over DOYs 143-146/2008 (22$25 \mathrm{May} / 1.21 \mathrm{~m} \mathrm{~s}^{-1}$ ) matches similar ground measurements $\left(1.7 \mathrm{~m} \mathrm{~s}^{-1}\right)$ made by Beltaos et al. (2012). Across the same cross-section of the MR, Kääb and Prowse (with imagery acquired 1-2 days earlier in 2008) estimated a preceding ice run ranging from 0 to $3.2 \mathrm{~m} \mathrm{~s}^{-1}$. The highest flow velocities were outlined where ice debris flow was most concentrated on the outside turn of the river bend. Finally, in another independent study, Beltaos and Kääb (2014) found ice debris velocities to range between 1 and $2 \mathrm{~m} \mathrm{~s}^{-1}$ using ALOS PRISM imagery in 2010. Again these high-resolution $(2.5 \mathrm{~m})$ image measurements compare quite well with our estimates from relatively coarse spatial resolution $(250-500 \mathrm{~m})$ MODIS imagery. Additionally, early investigations have re- ported that ice can clear at velocities of 0.27 and $0.44 \mathrm{~m} \mathrm{~s}^{-1}$ at Fort Simpson and Fort Good Hope respectively during the ice break-up season (Terroux et al., 1981).

MODIS is shown to be a viable tool for estimating riverice velocities. This study finds that in order to monitor ice cover the river width needs to at least $0.5-1 \mathrm{~km}$ wide. Furthermore, to quantify river-ice velocities, the river width needs to be at least $1 \mathrm{~km}$ wide. With respect to the MR, ice velocities were only quantifiable above the Ramparts. The presence of morphological controls and therefore river width shortening leading to impeded ice run prevented quantifying velocities, as leading river-ice demarcations were difficult to locate. However, it was possible to estimate the overall velocity by observing ice/open-water boundaries. Lastly, it was determined that in order to measure ice-run velocities without major disturbance with impeded flows with respect to river morphology, estimates with MODIS should be made north of the Ramparts. North of the Ramparts, river widths were generally observed to be largest with respect to other parts of the MR.

\section{Conclusion}

The aim of this study was to develop an approach to estimate ice break-up dates on the Mackenzie River over more than a decade using MODIS snow and radiance products. It was found that the initiation of ice break-up started on average DOYs $115-125$ and ended DOYs $145-155$ over the 13 years analysed. Thermal ice break-up was an important process driving ice break-up south of the Liard River. Conversely, north of the Liard, ice break-up was dynamically driven. The addition to discharge from the MR-Liard River confluence outlined a location where initial ice break-up began. Furthermore, MODIS images allowed for the identification of important factors controlling ice runs and ice break-up, including morphological controls such as channel bars, river meandering and channel constriction.

MODIS is currently the most promising tool for frequent monitoring of river-ice processes as ground-based stations along the Mackenzie River are continuously being closed. Operating aboard two satellites (Aqua and Terra), the MODIS sensor allows for multiple daily acquisitions simultaneously along extensive stretches of the MR. Furthermore, MODIS is proving to be a viable sensor for the monitoring of river ice as shown in this and other recent investigations (e.g. Chaouch et al., 2012). In this study, monitoring of ice breakup on the Mackenzie River with MODIS proved to be a robust approach when compared to WSC ground-based observations. MODIS observations also allowed for the analysis of basin level processes influencing ice break-up, including river morphology and snowmelt.

Finally, future research should focus on investigating riverice processes using a combination of ground-based and satellite-based sensors, particularly for examining relations 
between river morphology, ice strength and discharge. Data from these complementary technologies would be valuable in the context of an early warning system for municipalities where river-ice break-up is an important spring event causing significant flood damage. Furthermore, a multi-sensor approach using both optical and synthetic aperture radar (SAR) data would be advantageous in order to monitor ice river processes and floods in near real time. Satellite data from recent and upcoming SAR (Sentinel-1 and RADARSAT Constellation) and optical (Sentinel-2 and Sentinel-3) satellite missions will make such monitoring possible in the near future.

Acknowledgements. This research was supported by a NSERC Discovery grant number 193583-2012 to C. Duguay. We are grateful for the helpful comments of Ross Brown and two anonymous reviewers.

Edited by: R. Brown

\section{References}

Abdul Aziz, O. I. and Burn, D. H.: Trends and variability in the hydrological regime of the Mackenzie River Basin, J. Hydrol., 319, 282-294, doi:10.1016/j.jhydrol.2005.06.039, 2006.

Allen, W. T. R.: Freeze-up, Break-up and Ice Thickness in Canada: Embâcle, Débâcle Et Épaisseur de la Glace Au Canada, Environnement Atmosphérique, Downsview, Ontario, USA, 1977.

Beltaos, S.: Onset of river ice breakup, Cold Reg. Sci. Technol., 25, 183-196, doi:10.1016/S0165-232X(96)00011-0, 1997.

Beltaos, S.: Progress in the study and management of river ice jams, Cold Reg. Sci. Technol., 51, 2-19, 2008.

Beltaos, S.: Hydrodynamic characteristics and effects of river waves caused by ice jam releases, Cold Reg. Sci. Technol., 85, 42-55, doi:10.1016/j.coldregions.2012.08.003, 2013.

Beltaos, S. and Carter, T.: Field studies of ice breakup and jamming in lower Peace River, Canada, Cold Reg. Sci. Technol., 56, 102114, doi:10.1016/j.coldregions.2008.11.002, 2009.

Beltaos, S. and Kääb, A.: Estimating river discharge during ice breakup from near-simultaneous satellite imagery, Cold Reg. Sci. Technol., 98, 35-46, 2014.

Beltaos, S. and Prowse, T.: River-ice hydrology in a shrinking cryosphere, Hydrol. Process., 23, 122-144, doi:10.1002/hyp.7165, 2009.

Beltaos, S., Rowsell, R., and Tang, P.: Remote data collection on ice breakup dynamics: Saint John River case study, Cold Reg. Sci. Technol., 67, 135-145, doi:10.1016/j.coldregions.2011.03.005, 2011.

Beltaos, S., Carter, T., and Rowsell, R.: Measurements and analysis of ice breakup and jamming characteristics in the Mackenzie Delta, Canada, Cold Reg. Sci. Technol., 82, 110-123, 2012.

Chaouch, N., Temimi, M., Romanov, P., Cabrera, R., McKillop, G., and Khanbilvardi, R.: An automated algorithm for river ice monitoring over the Susquehanna River using the MODIS data, Hydrol. Process., 28, 62-73, doi:10.1002/hyp.9548, 2012.

Dee, D. P., Uppala, S. M., Simmons, A. J., Berrisford, P., Poli, P., Kobayashi, S., Andrae, U., Balmaseda, M. A., Balsamo, G.,
Bauer, P., Bechtold, P., Beljaars, A. C. M., van de Berg, L., Bidlot, J., Bormann, N., Delsol, C., Dragani, R., Fuentes, M., Geer, A. J., Haimberger, L., Healy, S. B., Hersbach, H., Hólm, E. V., Isaksen, L., Kållberg, P., Köhler, M., Matricardi, M., McNally, A. P., Monge-Sanz, B. M., Morcrette, J.-J., Park, B.-K., Peubey, C., de Rosnay, P., Tavolato, C., Thépaut, J.-N., and Vitart, F.: The ERA-Interim reanalysis: configuration and performance of the data assimilation system, Q. J. Roy. Meteor. Soc., 137, 553-597, doi:10.1002/qj.828, 2011.

De Munck, S., Gauthier, Y., Bernier, M., Poulin, J., and Chokmani, K.: Preliminary development of a geospatial model to estimate a river channel's predisposition to ice jams, in: 16th Workshop on Hydraulics of Ice Covered Rivers, Winnipeg, Manitoba, 1822 September 2011, CGU HS Committee on River Ice Processes and the Environment (CRIPE), 2011.

de Rham, L. P., Prowse, T. D., Beltaos, S., and Lacroix, M. P.: Assessment of annual high-water events for the Mackenzie River basin, Canada, Hydrol. Process., 22, 3864-3880, doi:10.1002/hyp.7016, 2008a.

de Rham, L. P., Prowse, T. D., and Bonsal, B. R.: Temporal variations in river-ice break-up over the Mackenzie River Basin, Canada, J. Hydrol., 349, 441-454, doi:10.1016/j.jhydrol.2007.11.018, 2008b.

Goulding, H. L., Prowse, T. D., and Beltaos, S.: Spatial and temporal patterns of break-up and ice-jam flooding in the Mackenzie Delta, NWT, Hydrol. Process., 23, 2654-2670, doi:10.1002/hyp.7251, 2009a.

Goulding, H. L., Prowse, T. D., and Bonsal, B.: Hydroclimatic controls on the occurrence of break-up and ice-jam flooding in the Mackenzie Delta, NWT, Canada, J. Hydrol., 379, 251-267, doi:10.1016/j.jhydrol.2009.10.006, 2009b.

Government of Canada, E. C.: Environment Canada - Water Rivers, available at: http://www.ec.gc.ca/eau-water/default.asp? lang=En\&n=45BBB7B8-1, last access: 7 June 2014, 2007.

Government of Canada, E. C.: Environment Canada - Water Environment Canada Data Explorer, available at: http://www. ec.gc.ca/rhc-wsc/default.asp?lang=En\&n=0A47D72F-1, last access: 27 March 2013, 2010.

Hall, D. D. K., Riggs, D. G. A., and Salomonson, D. V. V.: MODIS snow and sea ice products, in: Earth Science Satellite Remote Sensing, edited by: Qu, P. J. J., Gao, D. W., Kafatos, P. M., Murphy, D. R. E., and Salomonson, D. V. V., Springer, Berlin, Heidelberg, 154-181, 2006.

Hicks, F.: An overview of river ice problems: CRIPE07 guest editorial, Cold Reg. Sci. Technol., 55, 175-185, 2009.

Kääb, A. and Prowse, T.: Cold-regions river flow observed from space, Geophys. Res. Lett., 38, L08403, doi:10.1029/2011GL047022, 2011.

Kääb, A., Lamare, M., and Abrams, M.: River ice flux and water velocities along a $600 \mathrm{~km}$-long reach of Lena River, Siberia, from satellite stereo, Hydrol. Earth Syst. Sci., 17, 4671-4683, doi:10.5194/hess-17-4671-2013, 2013.

Lenormand, F., Duguay, C. R., and Gauthier, R.: Development of a historical ice database for the study of climate change in Canada, Hydrol. Process., 16, 3707-3722, 2002.

MacKay, D. K.: Mackenzie River and Delta ice survey, 1965, Geogr. Bull., 8, 270-278, 1966.

MacKay, D. K. and Mackay, J. R.: Locations of Spring Ice Jamming on the Mackenzie River, N. W. T. Environ.-Soc. Com. North. 
Pipelines Task Force North. Oil Dev. Rep. No. 73-3 Technical Report 8, North Pipelines Task Force North, Ottawa, 1973.

Magnuson, J. J., Robertson, D. M., Benson, B. J., Wynne, R. H., Livingstone, D. M., Arai, T., Assel, R. A., Barry, R. G., Card, V., Kuusisto, E., Granin, N. G., Prowse, T. D., Stewart, K. M., and Vuglinski, V. S.: Historical trends in lake and river Ice cover in the Northern Hemisphere, Science, 289, 1743-1746, doi:10.1126/science.289.5485.1743, 2000.

Pavelsky, T. M. and Smith, L. C.: Spatial and temporal patterns in Arctic river ice breakup observed with MODIS and AVHRR time series, Remote Sens. Environ., 93, 328-338, doi:10.1016/j.rse.2004.07.018, 2004.

Prowse, T. D.: River-ice ecology. I: Hydrologic, geomorphic, and water-quality aspects, J. Cold Reg. Eng., 15, 1-16, doi:10.1061/(ASCE)0887-381X(2001)15:1(1), 2001.
Prowse, T. D. and Beltaos, S.: Climatic control of riverice hydrology: a review, Hydrol. Process., 16, 805-822, doi:10.1002/hyp.369, 2002.

Riggs, G. A., Barton, J. S., Casey, K. A., Hall, D. K., and Salomonson, V. V.: MODIS Snow Products Users' Guide, NASA GSFC, Greenbelt, MD, USA, 2000.

Terroux, A. C. D., Sherstone, D. A., Kent, T. D., Anderson, J. C., Bigras, S. C., and Kriwoken, L. A.: Ice regime of the lower Mackenzie River and Mackenzie Delta, Environ. Can. Natl. Hydrol. Res. Inst., Hull, Quebec, 1981.

Woo, M.-K. and Thorne, R.: Streamflow in the Mackenzie Basin, Canada, Arctic, 56, 328-340, 2003. 